\title{
Geology and mineralogy of advanced argillic alteration in the Keshe area (Mt. Karkas), Central Iran
}

\author{
Batoul Taghipour, \\ Mohammad Ali Mackizadeh \\ Geology Department, Esfahan University, Esfahan, \\ Iran
}

\author{
Mehdi Pourmoghani \\ College of Public Health, University of South \\ Florida, Tampa, Florida, USA
}

Sedighe Taghipour

Geology Department, Tehran University, Tehran Iran

Cornell Isotope Laboratory, Cornell University, Ithaca, NY USA

The Keshe area is a part of Cenozoic magmatic belt of Central Iran. Some volcanics in this area underwent hydrothermal alteration including kaolinitization and alunitization. The altered rocks are characterized by an assemblage of alunite, kaolinite and quartz, which is typical in advanced argillic alteration. The mineralogical study suggests that the hydrothermal alteration in this area occurred in a magmatic hydrothermal environment.

Key words: hydrothermal alteration, alunite, kaolinite, Cenozoic magmatic belt, Central Iran

\section{Introduction}

The village of Keshe is located around 85 kilometers north of the city of Isfahan in Central Iran. The studied area exposes a sequence of Cenozoic magmatic rocks of calc-alkaline series. This formation forms a part of the long volcano-plutonic belt in Iran (Uroumia-Dokhtar Volcanic Belt) (Fig. 1) running parallel to the Zagros-Central Iranian convergent plate margin (Pourhosseni 1981). There are some occurrences of hydrothermal alteration in the volcanics in this studied area. This paper describes the geology and mineralogy of the altered rocks in the Keshe village area, in order to clarify the characteristics of the hydrothermal alteration.

Addresses: B. Taghipour, M. A. Mackizadeh, M. Pourmoghani, S. Taghipour: Geology Department, Esfahan University, Esfahan, Iran, Postal Code: 81746-73441,

e-mail: goharrr@yahoo.com

A. Kasson: E440 Corson Hall, Tower Road; Cornell University, Ithaca, NY 14853

Received: September 9, 2007; accepted: June 11, 2008 


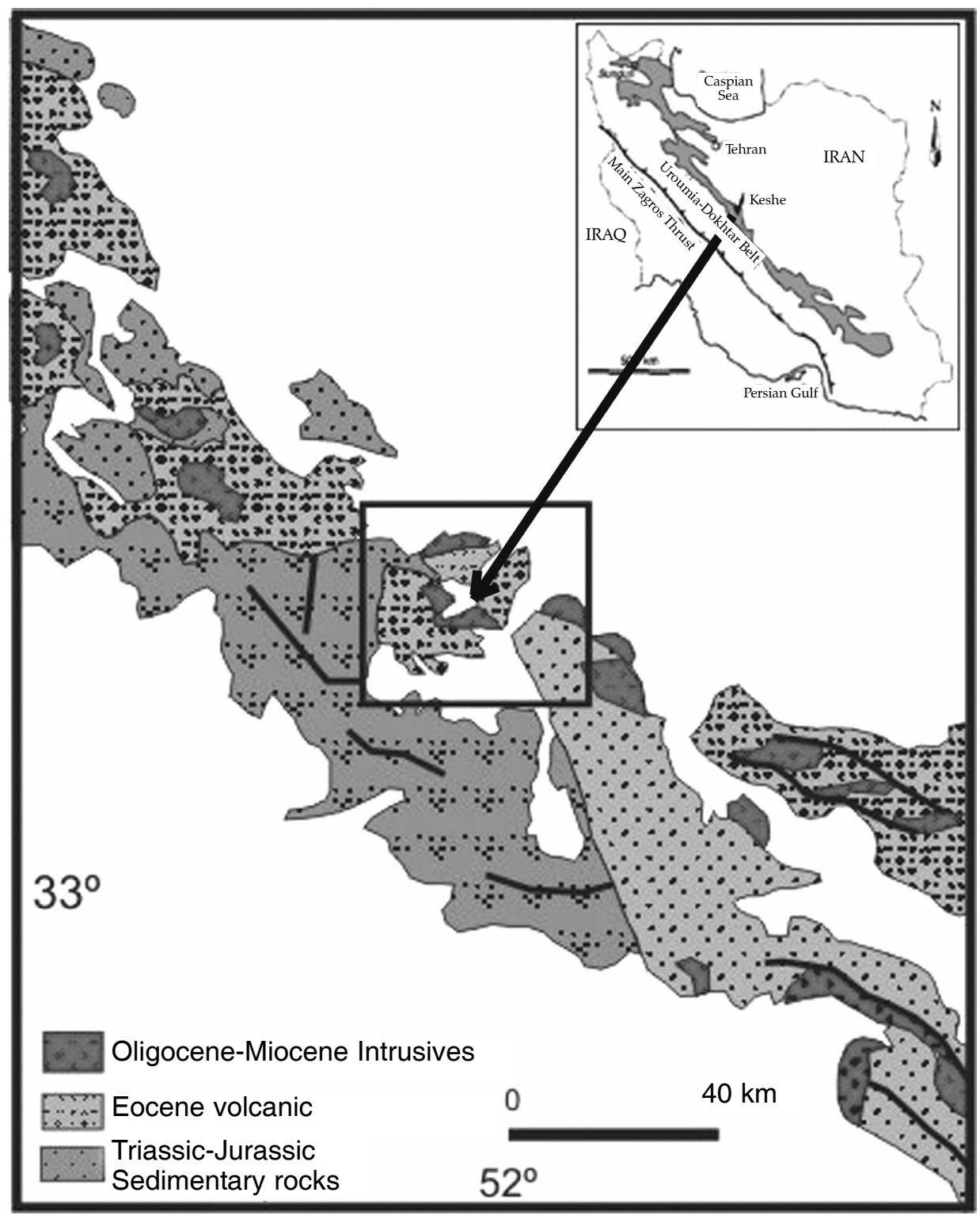

Fig. 1

Map of Iran showing the position of the Cenozoic magmatic belt (Uromieh-Dokhtar Belt) of Central Iran (modified after Kazmin et al. 1986) and geologic map of the Keshe area (modified after Pourhosseini 1981) 


\section{Analytical methods}

Two hundred samples were collected from the surface of the Keshe area. Of these samples, 50 samples are altered pyroclastic rocks, which were observed under a polarizing microscope BX-60 for mineralogy studies.

X-ray diffractometery was used to identify the alunite-group and kaolinitegroup minerals for 20 samples, because these minerals are generally fine in size and difficult to identify with the naked eye. Scanning electron microscopy was used for identification of the hydrated sulfate minerals. On the basis of the mineralogical and chemical data 20 EDS analyses were made on 3 alunite-bearing samples and 2 kaolinite samples from the altered volcanics.

\section{Geology of the Keshe area}

The surface of the area is largely covered by Triassic-Jurassic sedimentary rocks (Fig. 1). These sediments are composed of quartzite and sandstone beds, with shale and siltstone levels and intercalations of ammonite-bearing limestone (Zahedi 1976). Structurally the area is strongly deformed and these sedimentary rocks are in fault contact with Cenozoic magmatic rocks (Fig. 1).

In northern parts of area there is a thick and widespread sequence of volcanic and pyroclastic rocks with some tuffaceous sediments, which builds up the Karkas Mountain (Fig. 2). Several phases of volcanic activity are reported from the Eocene volcanic succession of the area (Amidi 1975, 1977).

The Miocene-Oligocene plutonic bodies, ranging from gabbro to granite in composition, are intruded successively into the Eocene volcanic rocks. The Quaternary section contains large travertine deposits in the southern part of the area.

The Eocene volcanic rocks, which underwent hydrothermal alteration, belong mainly to the tuffaceous unit; a minor portion of the andesite unit was also altered. There are also some altered dacitic rocks. The general features of the mineralogy and petrography of these rocks are described below.

Cryptocrystalline matrix is common in tuff. Fragments of other volcanic and sedimentary rocks, as well as quartz and feldspar crystals, are present in the tuff. The andesite lavas are commonly porphyritic. Phenocrysts of plagioclase, hornblende with a little augite, and biotite are surrounded by a fine-grained groundmass of plagioclase microlites and opaque cryptocrystalline matrix.

The XRF analytical results (Table 1) indicate that most of these rocks are trachyandesitic in composition (Fig. 3).

Field observations revealed that two small kaolinite-alunite deposits are located within the area of hydrothermally-altered volcanics in Keshe. Alunitization and kaolinitization are the dominating hydrothermal alteration processes in this area, occasionally associated with weak silicification. Patches of microcrystalline quartz with pyrite are present, especially within alunitized rocks on the border of the kaolinitization zones. 


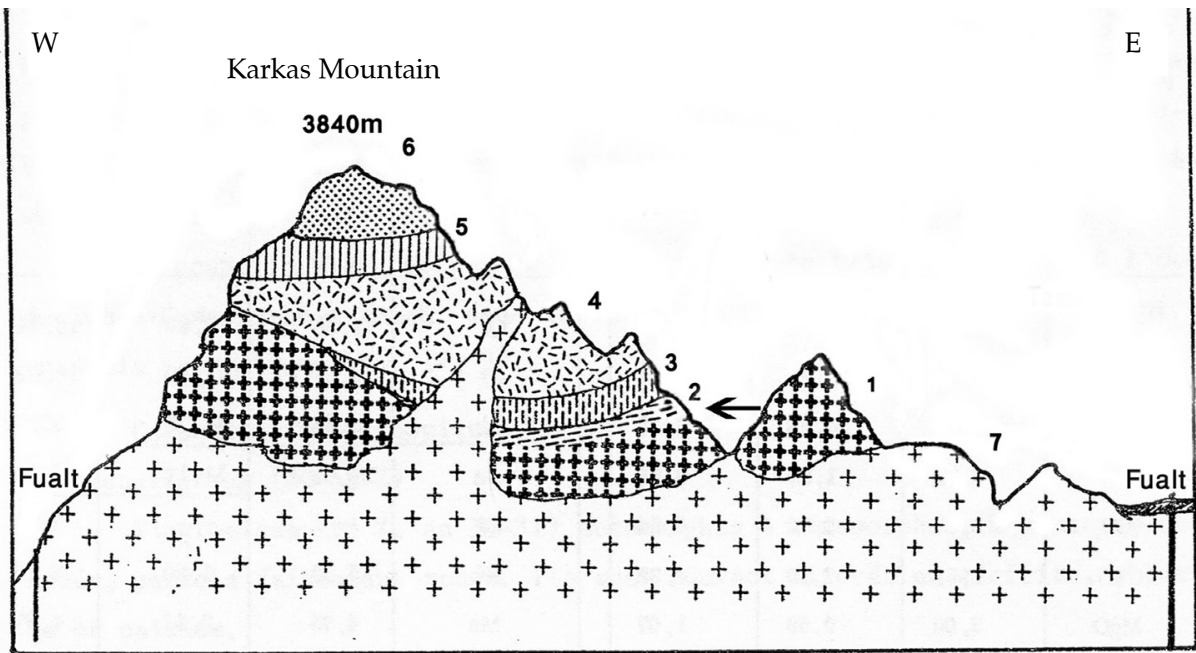

Fig. 2

Cross-section through Mt. Karkas and the position of the altered rocks in the volcanic succession (modified after Amidi 1975). 1. Basaltic andesites; 2. Reddish tuffs (lithic and brecciated), 3. Dark colour dacites; 4. Andesitic rocks; 5. Pyroclastic rocks; 6. Greenish andesites; 7. Plutonic miocene rocks; $\rightarrow$ Hydrothermal alteration

Table 1

Major element (wt $\%$ ) chemical composition of unaltered Eocene volcanics from Keshe

\begin{tabular}{|c|c|c|c|c|c|c|c|c|c|}
\hline Sample & $\mathbf{S i O}_{2}$ & $\mathbf{A l}_{2} \mathbf{O}_{3}$ & $\mathbf{F e}_{2} \mathbf{O}_{3}$ & $\mathbf{M g O}$ & $\mathbf{C a O}$ & $\mathbf{N a}_{2} \mathbf{O}$ & $\mathbf{K}_{2} \mathbf{O}$ & $\mathbf{T i O}_{2}$ & $\mathbf{P}_{\mathbf{2}} \mathbf{O}_{\mathbf{5}}$ \\
\hline 344 & 58.01 & 16.45 & 4.69 & 3.25 & 5.25 & 4.54 & 3.39 & 1.78 & 0.13 \\
\hline 345 & 59.16 & 16.86 & 4.82 & 2.33 & 4.68 & 4.09 & 3.04 & 0.815 & 0.15 \\
\hline 346 & 58.44 & 16.36 & 4.11 & 3.30 & 4.24 & 4.11 & 3.06 & 1.36 & 0.31 \\
\hline 347 & 57.36 & 16.07 & 7.47 & 3.72 & 4.45 & 4.33 & 3.46 & 0.90 & 0.11 \\
\hline 349 & 50.99 & 20.82 & 4.55 & 4.94 & 4.86 & 4.77 & 3.34 & 1.05 & 0.20 \\
\hline 350 & 54.24 & 16.59 & 4.89 & 4.95 & 6.80 & 2.98 & 1.75 & 0.98 & 0.27 \\
\hline 351 & 58.32 & 14.00 & 6.40 & 3.84 & 4.45 & 3.61 & 2.37 & 1.29 & 0.27 \\
\hline 352 & 60.69 & 17.02 & 4.64 & 1.79 & 6.24 & 3.78 & 0.93 & 0.78 & 0.15 \\
\hline 353 & 57.07 & 19.04 & 3.80 & 2.99 & 6.29 & 2.86 & 1.83 & 0.97 & 0.17 \\
\hline 354 & 58.12 & 18.45 & 4.01 & 3.52 & 4.40 & 3.20 & 1.20 & 0.99 & 0.23 \\
\hline
\end{tabular}

The primary textures of the pyroclastic rocks exposed in quarries are commonly completely obscured, but may be preserved in areas of less extensive alteration.

In the surveyed area the alunitization zones are characterized by two distinct shapes; dike-like bodies, which show fracture zones in the volcanics (Fig. 4a) and replacement bodies. Alunite which is related to fracture zones has obvious 
Fig. 3

$\mathrm{Na}_{2} \mathrm{O}+\mathrm{K}_{2} \mathrm{O}$ versus $\mathrm{SiO}_{2}$ plot of Cox et al. (1987) for the volcanics

breccia texture in outcrops; the primary porphyritic texture of volcanics prior to alteration is well preserved only in replacement alunite. Every alunite occurrence shows cream to reddish brown color (Fig. 4a), but kaolinitized rocks are white in color (Fig. 4b).
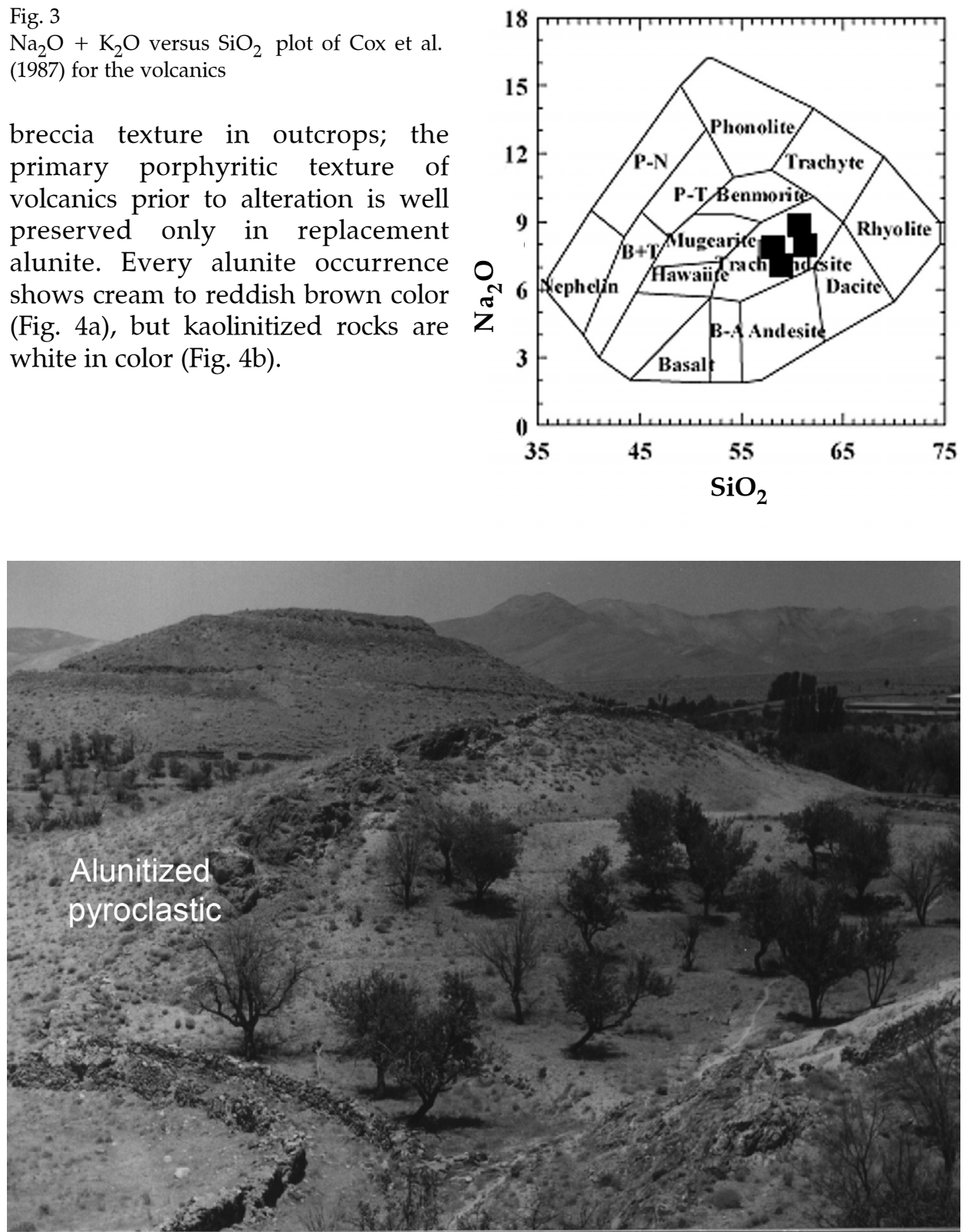

Fig. 4a

Alunitized fracture zone in pyroclastic rocks 


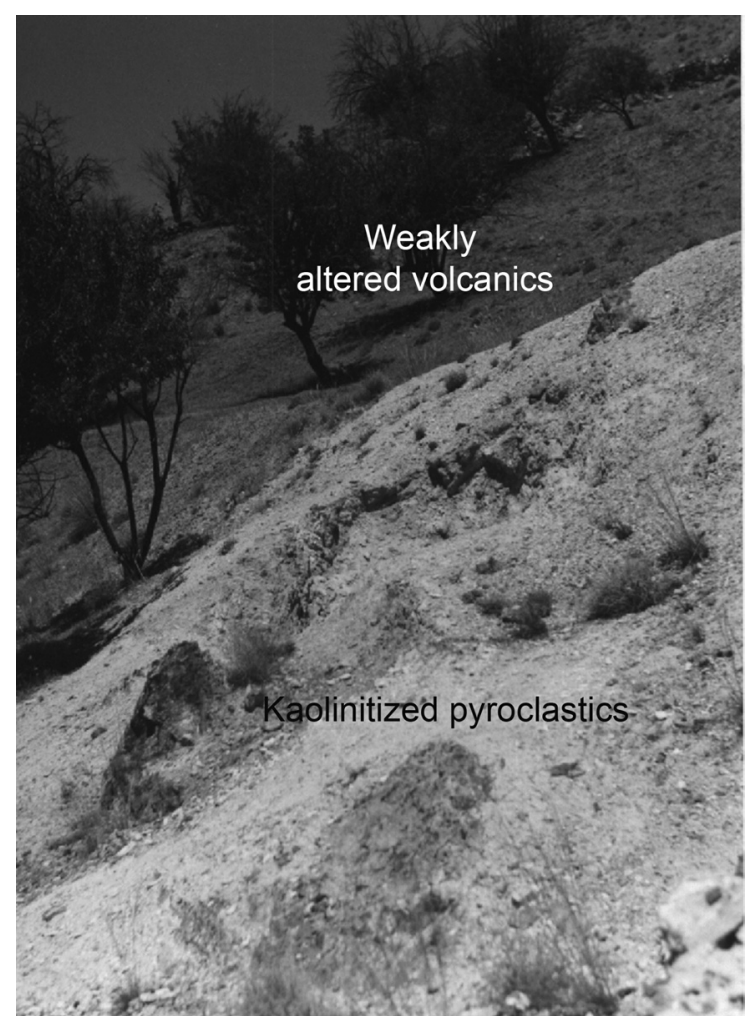

Fig. $4 \mathrm{~b}$

Kaolinitization in Eocene pyroclastic rocks

Table 2

Mineral assemblages detected by XRD analysis

\begin{tabular}{|c|c|c|c|}
\hline Sample & Area & Index mineral & Associated minerals \\
\hline K-1 & East Keshe & Kaolinite & Quartz + Anatase + Illite \\
\hline K-2 & East Keshe & Jarosite & Quartz + Clay minerals \\
\hline K-3 & North East Keshe & Kaolinite & Quartz \\
\hline K-4 & North East Keshe & Kaolinite & Quartz + Hematite + Calcite \\
\hline K-5 & North of Keshe & Alunite & Rutile + Quartz + Kaolinite \\
\hline K-6 & North of Keshe & Alunite & Quartz + Kaolinte \\
\hline K-7 & Keshe & Kaolinite & Quartz + Alunite \\
\hline K-8 & Keshe & Kaolinite & Quartz + Alunite + Hematite \\
\hline K-9 & Keshe & Kaolinite & Quartz + Alunite \\
\hline
\end{tabular}


Geology and mineralogy of advanced argillic alteration in the Keshe area (Mt. Karkas), Central Iran 91

\section{Mineralogy}

The main mineral assemblage identified by $\mathrm{X}$-ray diffractometry includes alunite, kaolinite and quartz (Table 1).

Alunitized rocks are mostly composed of massive alunite with subordinate amounts of quartz (Fig. 5a). Alunite displays a wide variety of grain size ranging from cryptocrystalline $(<20 \mu \mathrm{m})$ to microcrystalline $(50-100 \mu \mathrm{m})$. The cryptocrystalline type occurs in a groundmass of the rocks (Fig. 5b); coarse-grained alunite, which shows a microgranular texture, occurs as irregular patches in altered rocks (Fig. 5c). Veinlet occurrences of alunite with variable size in altered rocks (Fig. 5d, e) are common in the studied area. Alunite crystals are clear with low relief in ppl and show low first-order gray to yellow interference colors in xpl.

Some coarse open space-filling alunite in veinlets and vugs (typically up to 150 $\mu \mathrm{m}$ in diameter) (Fig. 5f) shows higher birefringence than the other occurrences, from first order gray to second-order blue. The alunitized rocks well preserve the porphyritic texture of the primary rocks. Alunite replaces rock-forming minerals of primary volcanics, with the exception of quartz (Fig. 5a). Replacement of very fine-grained alunite in some lithic fragments of tuff is provided by ghost texture (Fig. $5 \mathrm{~g}$ ). In most altered rocks there are no crack and seal textures, suggesting that the alunitization was mainly pervasive.

In the kaolinitized volcanics, feldspar phenocrysts are identified in the ppl view by cloudy appearance due to alteration (Fig. 5h).

\section{Geochemical studies}

Only two samples of fairly pure alunite and kaolinite which were analyzed by EDS are presented in Fig. 6. Table 3 shows three EDS analyses of alunite. The samples of every lithology described above were analyzed for major elements (Table 4). Concentration of the major elements ( $\mathrm{Si}, \mathrm{Al}, \mathrm{K}), \mathrm{S}$ and volatile correlated well with the mineral assemblages. For example the rocks with high alunite content $(\mathrm{K}-10,-11$ and -12$)$ are characterized by high $\mathrm{Al}, \mathrm{K}, \mathrm{SO}_{3}$ contents. These samples also contain some $\mathrm{Na}_{2} \mathrm{O}$.

This result suggests that the alunite is a solid solution between alunite $\left[\mathrm{KAl}_{3}\right.$ $\left.\left(\mathrm{SO}_{4}\right)_{2}(\mathrm{OH})_{6}\right]$ and natroalunite $\left[\mathrm{NaAl}_{3}\left(\mathrm{SO}_{4}\right)_{2}(\mathrm{OH})_{6}\right]$. The alunite formed at a higher temperature is usually high in sodium content (Stoffregen and Cyan 1990).

These samples also contain minor amounts of $\mathrm{P}_{2} \mathrm{O}_{5}$ (Table 4). The occurrence of phosphate and/or aluminum-phosphate in the fine-grained alunite is a unique attribute of advanced argillic alteration in a magmatic hydrothermal environment (Rye and Bethke 1992). Some pure kaolinitized samples were also analyzed for some trace elements (Table 5). The data are used to discriminate the geologic environment of kaolin formation according to Dill et al. (1997). $\mathrm{Cr}+\mathrm{Nb}$ versus $\mathrm{Fe}+\mathrm{Ti}$ are one of the diagrams which are used (Fig. 7a). Cr may substitute 

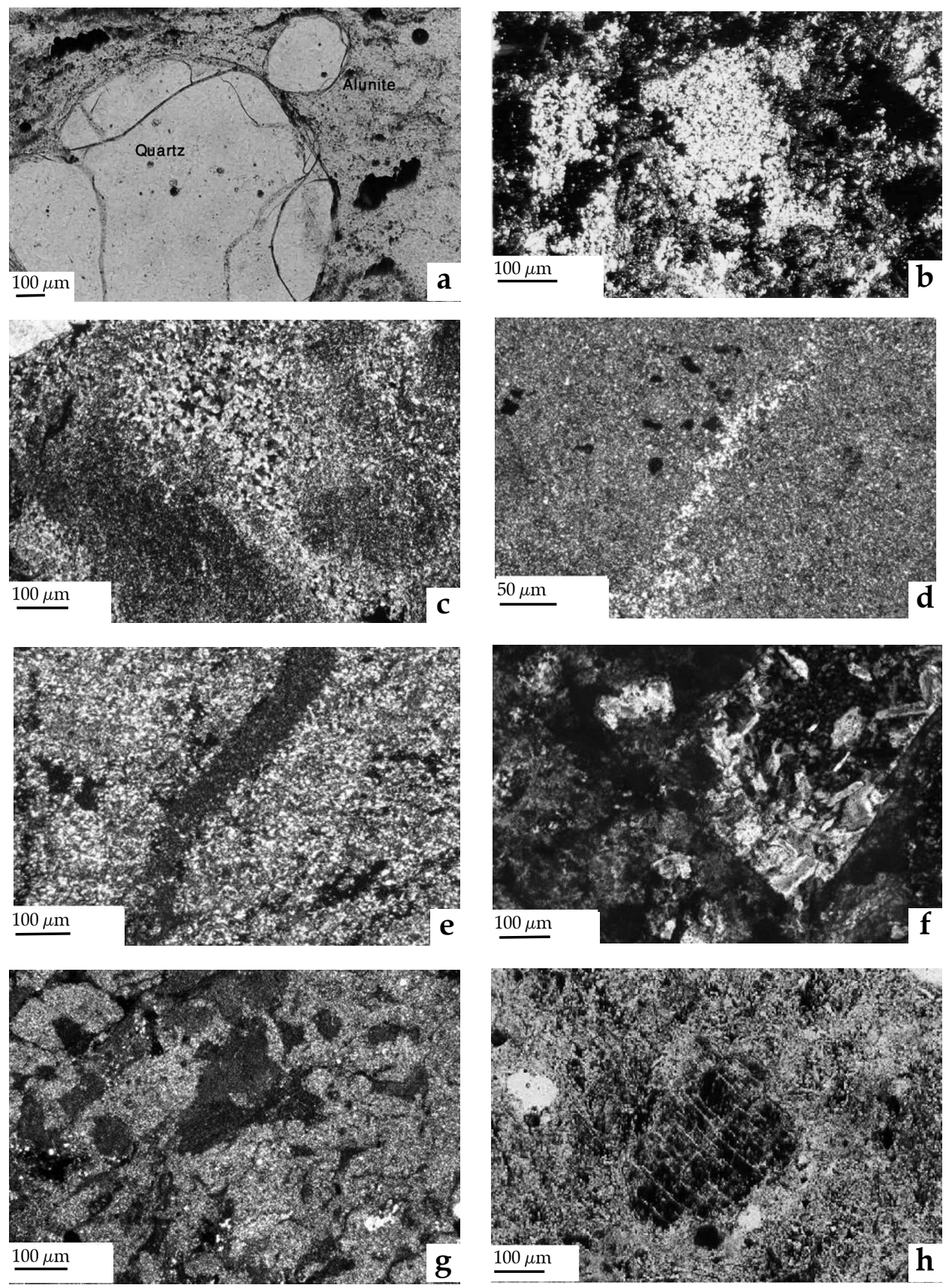

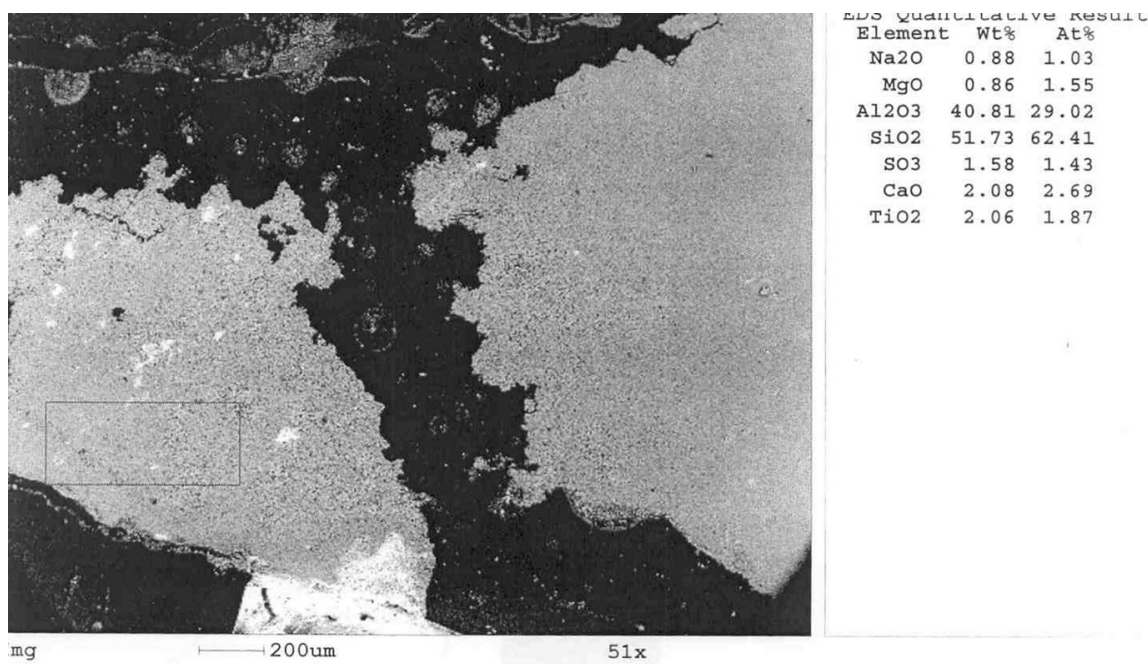

$\mathrm{mg}$

$51 x$
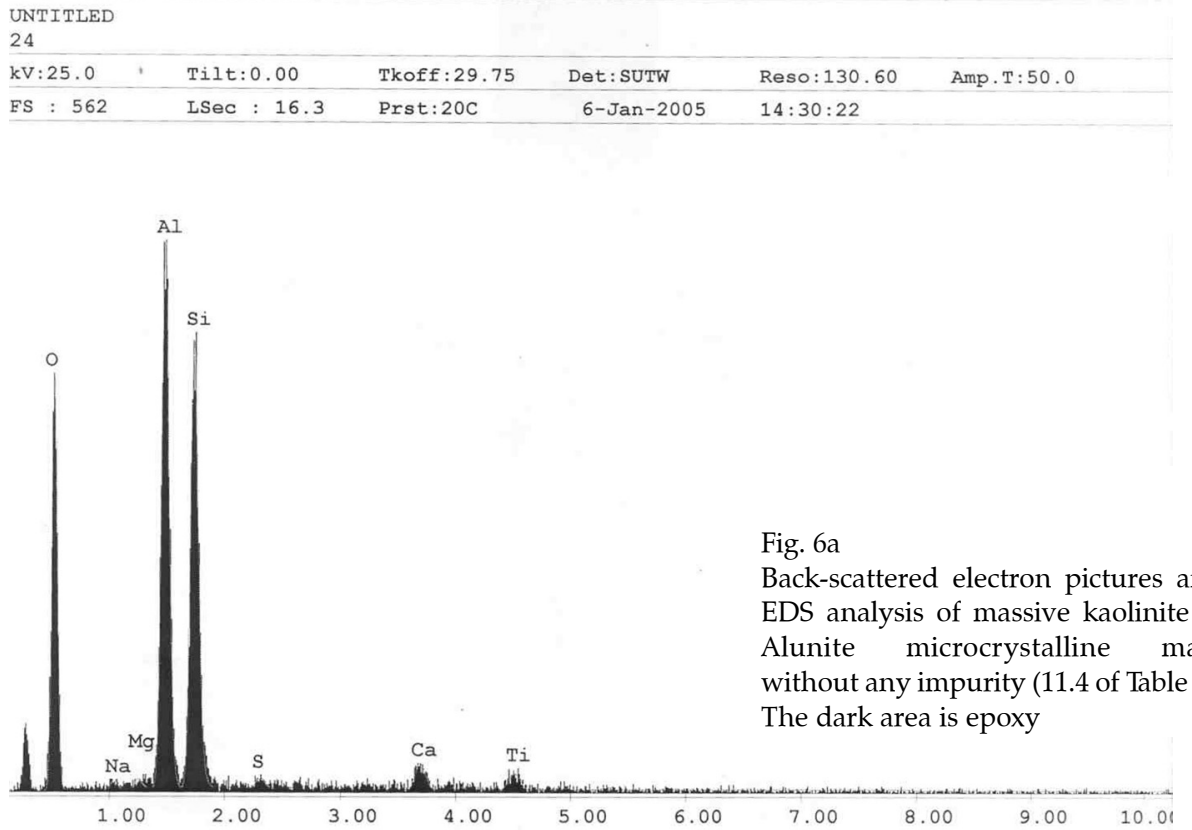

$\leftarrow$ Fig. 5

a) Two embayed phenocrysts of quartz which are relicts of initial dacite in a fine-grained matrix of alunite. They are clear and unaltered. b) Fine-grained alunite in altered pyroclastics. c) A patch of coarse granular alunite in a groundmass of fine-grained alunite. $d$ ) Veinlet of fine grained alunite in a groundmass of alunite. e) Cryptocrystalline alunite as veinlet in a groundmass of alunite. f) Openspace filling crystal of alunite up to $150 \mu \mathrm{m}$ in size. g) Preservation of primary detrital texture of pyroclastic tuff. The lithic fragments are completely replaced by very fine-grained alunite. h) Kaolinitization of a feldspar phenocryst 

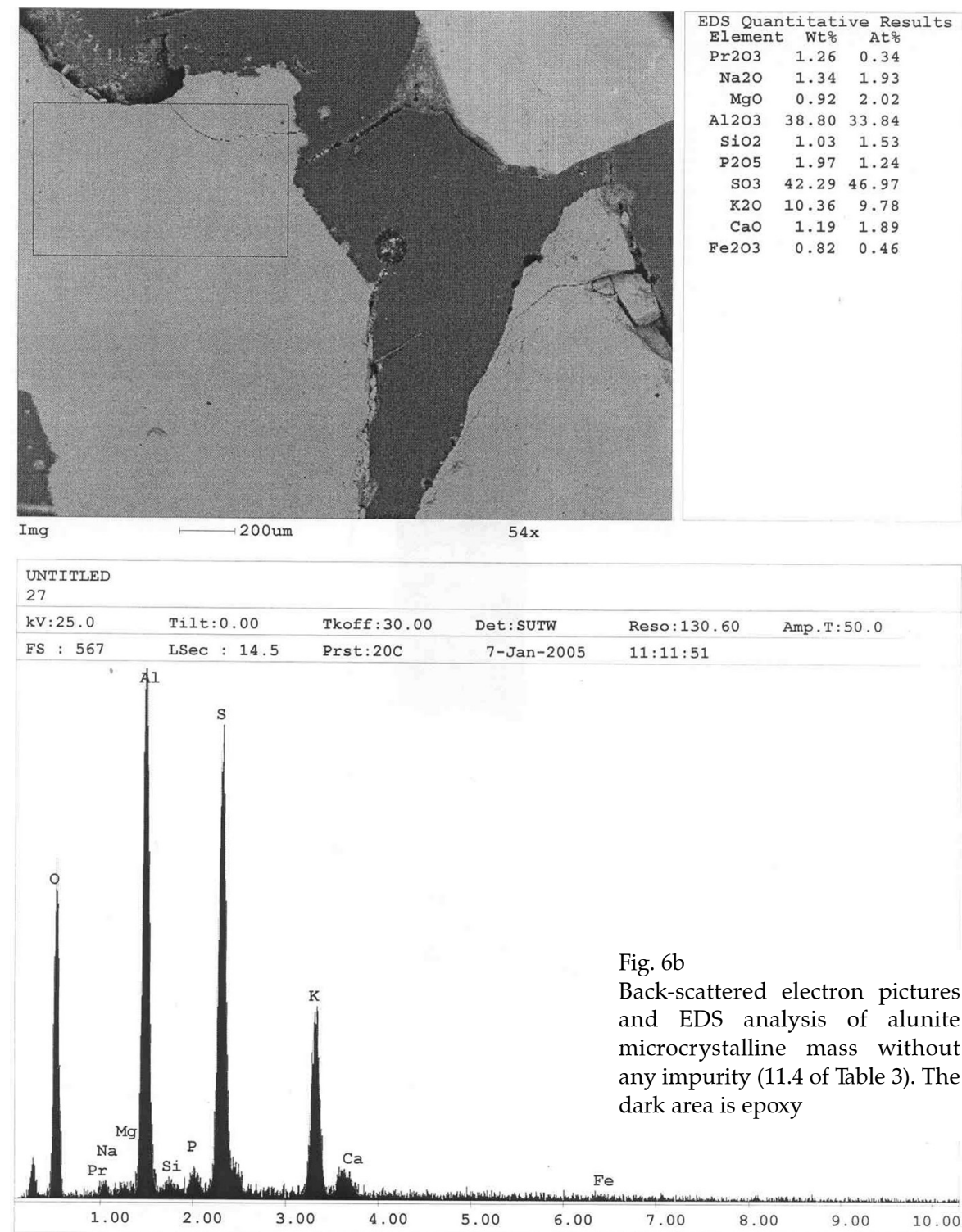

for tetravalent $\mathrm{Ti}$ in $\mathrm{TiO}_{2}$ modifications and for trivalent $\mathrm{Fe}$ in goethite during supergene kaolinization (Köster 1974). $\mathrm{Nb}$ is known to be concentrated in $\mathrm{Ti}$ minerals as well, due to the similar ionic ratio. Samples from pure supergene kaolin deposits contain high $\mathrm{Cr}$ and $\mathrm{Nb}$, whereas these elements are very low in hypogene deposits (Dill 2005). Cr only forms soluble species below $\mathrm{pH} 4-5$ depending on the activity of $\mathrm{Cr}\left(10^{-4}\right.$ to $\left.10^{-6}\right)$ and above $\mathrm{pH} 13.5$ (Dill 2005). Hydrothermal kaolin deposits in which alunite coexists with kaolinite probably 
Table 3

Representative electron microprobe (EDS) compositions of alunite

\begin{tabular}{|c|c|c|c|c|c|c|c|c|c|}
\hline Sample & Rock type & $\mathbf{A l}_{2} \mathbf{O}_{3}$ & $\mathbf{S i O}_{2}$ & $\mathbf{N a}_{2} \mathbf{O}$ & $\mathbf{K}_{2} \mathbf{O}$ & $\mathbf{F e}_{2} \mathbf{O}_{3}$ & $\mathbf{S O}_{3}$ & $\mathbf{P}_{2} \mathbf{O}_{5}$ & Total \\
\hline 11.4 & Alunitized volcanic rock & 41.40 & - & 3.97 & 7.00 & - & 48.27 & - & 100.64 \\
\hline 11.5 & Alunitized volcanic rock & 41.44 & - & 4.19 & 6.97 & - & 47.6 & - & 100.20 \\
\hline 11.7 & Alunitized volcanic rock & 41.50 & - & 3.46 & 7.64 & - & 47.42 & - & 100.02 \\
\hline
\end{tabular}

Table 4

$\mathrm{XRF}$ analysis results of major element composition of altered rocks

\begin{tabular}{|c|c|c|c|c|c|c|c|c|c|c|c|c|}
\hline Sample & Rock type & $\mathbf{S i O}_{2}$ & $\mathbf{A l}_{2} \mathbf{O}_{3}$ & $\mathbf{F e}_{2} \mathbf{O}_{3}$ & $\mathbf{M g O}$ & $\mathbf{C a O}$ & $\mathbf{N a}_{2} \mathbf{O}$ & $\mathbf{K}_{2} \mathbf{O}$ & $\mathbf{T i O}_{2}$ & $\mathbf{P}_{2} \mathbf{O}_{5}$ & $\mathbf{S O}_{3}$ & $\mathbf{L O I}$ \\
\hline K-1 & $\begin{array}{c}\text { Brown } \\
\text { kaolinitized rock }\end{array}$ & 50.1 & 30 & 3.74 & 0.02 & 0.64 & 0.14 & 0.05 & 0.29 & 0.18 & 0.60 & 13.90 \\
\hline K-4 & $\begin{array}{c}\text { White } \\
\text { kaolinitized rock }\end{array}$ & 62.4 & 35.1 & 0.13 & 0.2 & 0.11 & 0.04 & 0.02 & 0.34 & 0.12 & 0.39 & 0.97 \\
\hline K-7 & $\begin{array}{c}\text { White } \\
\text { kaolinitized rock }\end{array}$ & 58.09 & 36.52 & 0.27 & 0.09 & 0.27 & 0.35 & 0.77 & 0.77 & 0.55 & 1.61 & - \\
\hline K-10 & Alunitized rock & 2.06 & 31.5 & 0.15 & - & - & 2.63 & 6.08 & - & 0.11 & 33.6 & - \\
\hline K-11 & $\begin{array}{c}\text { Alunitized and } \\
\text { kaolinitized rock }\end{array}$ & 30.2 & 31.2 & 1.68 & - & - & 2.35 & 4.84 & - & 0.23 & 30.2 & - \\
\hline K-12 & Alunitized rock & 2.97 & 31.3 & 0.08 & - & - & 2.31 & 9.00 & - & 0.26 & 47.9 & - \\
\hline
\end{tabular}

requires $\mathrm{pH}<4$; such a low $\mathrm{pH}$ is not attained in supergene environments. The hydrothermal kaolinite-alunite association requires an environment with $\mathrm{pH}<4$. The other diagram is $\mathrm{Ce}+\mathrm{Y}+\mathrm{La}$ versus $\mathrm{Ba}+\mathrm{Sr}$ (Fig. $\mathrm{7b}$ ). Ba and Sr substitute for each other and are mainly found in barite, which conversely occurs in hypogene deposits. Ce, Y and La are considerably enriched during bauxitization and supergene kaolinitization (Maksimovic and Pantó 1983; Dill et al. 1995), as well as in hypogene phosphate and aluminum phosphate minerals (woodhouseite and svanbergite); see Watanabe and Hedenquist (2001). Thus, these mineralogical and geochemical data suggest that the advanced argillic alteration at Keshe is hypogene in origin.

\section{Conclusions}

Alunite is a common mineral occurring in advanced argillic alteration in alumino-silicate rocks (Meyer and Hemly 1967; Stoffregen 1987). Keshe is the first occurrence of this kind of alteration described in Central Iran with geologic, mineralogical and geochemical data. 
a
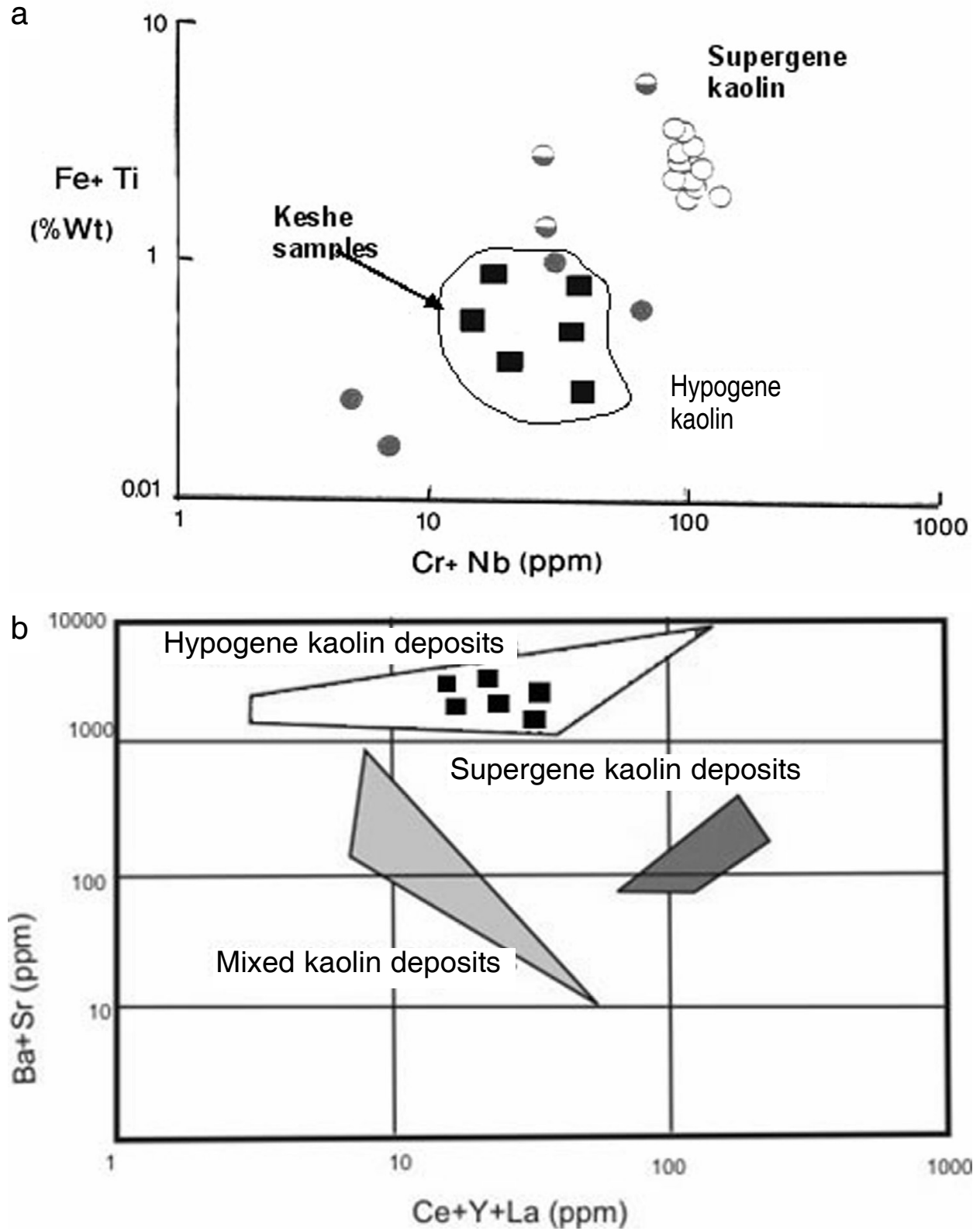

Fig. 7a, b

Discriminations of hypogene and supergene kaolinites on the base of chemical compositions (Dill et al. 1997). (The position of Keshe kaolinites is shown by $\boldsymbol{\square}$ ) 
Table 5

$\mathrm{XRF}$ analysis results of trace element chemical compositions of kaolinitized rocks

\begin{tabular}{|c|c|c|c|c|c|c|c|c|c|c|c|c|c|c|c|c|c|c|c|}
\hline Sample & Host Rock & $\mathbf{Z r}$ & $\mathbf{B a}$ & $\mathbf{C e}$ & $\mathbf{L a}$ & $\mathbf{Y}$ & $\mathbf{V}$ & $\mathbf{T h}$ & $\mathbf{U}$ & $\mathbf{C r}$ & $\mathbf{Z n}$ & $\mathbf{N d}$ & $\mathbf{W}$ & $\mathbf{H f}$ & $\mathbf{N b}$ & $\mathbf{N i}$ & $\mathbf{G a}$ & $\mathbf{R b}$ & $\mathbf{S r}$ \\
\hline K-4 & $\begin{array}{c}\text { White } \\
\text { kaolinitized rock }\end{array}$ & 7 & 554 & 17 & 8 & 32.5 & 380 & 1 & 1 & 65 & 22 & - & $<1$ & - & 22 & 2 & 7 & 8 & 414 \\
\hline K-5 & $\begin{array}{c}\text { White } \\
\text { kaolinitized rock }\end{array}$ & 6 & 550 & 20 & 3 & 30.4 & 220 & 3 & 4 & 60 & 20 & 2 & 1 & 20 & 20 & 3 & 4 & 6 & 369 \\
\hline K-6 & $\begin{array}{c}\text { White } \\
\text { kaolinitized rock }\end{array}$ & 20 & 498 & 23 & 5 & 2 & 250 & 2 & 3 & 44 & 15 & - & 0 & 10 & 5 & 5 & 8 & 8 & 412 \\
\hline K-7 & $\begin{array}{c}\text { White } \\
\text { kaolinitized rock }\end{array}$ & 40 & 446 & 48 & 0 & 0 & 272 & 3 & 29 & 37 & 13 & 26 & 0 & 39 & 10 & 10 & 19 & 9 & 427 \\
\hline
\end{tabular}

Replacement, variation in grain size of alunite, some open space filling and crosscutting textures of alunite in microscopic studies record a paragenetic sequence of alteration events that resulted in the Keshe alteration site.

The relatively coarse-grained $(50-100 \mu \mathrm{m})$ nature of the Keshe alunite is consistent with an environment with high-sulfidation quartz alunite assemblages formed at $>200{ }^{\circ} \mathrm{C}$, according to Hedenquist et al. (2000). The mineralogy of this alteration site is characteristic of hydrothermal alteration due to condensation of magmatic vapors by meteoric water.

\section{Acknowledgements}

The authors of this paper respectfully thank Isfahan University, Islamic Republic of Iran for the full support for Miss B. Taghipour's PhD dissertation.

They also thank Dr. I. Noorbehesht for his scientific supervision, Dr. M. Khalili for the EDS analyses at the University of Oklahoma City, as well as Dr. Y. Watanabe for editing and for his scientific cooperation.

\section{References:}

Amidi, S.M. 1975: Contribution à l'étude stratigraphique, pétrologique et pétrochimique des roches magmatiques de la région Natanz-Nain-Surk (Iran Central). - PhD thesis, Grenoble, $316 \mathrm{p}$.

Amidi, S.M. 1977: Étude géologique de la région de Natanz-Surk (Iran Central), stratigraphie et pétrologie. - Geology Survey of Iran, 42, 316 p.

Cox, K.G., J.D. Bell, R.J. Pankhurst 1979: The interpretation of igneous rocks. - George Allen and Unwin, London, $450 \mathrm{p}$

Dill, H.G. 2005: The geology of aluminum phosphates and sulphates of the alunite group minerals: a review. - Mineralium Deposita, 53, pp. 35-93.

Dill, H.G., H.R. Bosse, K.H. Henning, A. Fricke, H. Ahrendt 1997: Mineralogical and chemical variations in hypogene and supergene kaolin deposits in a mobile fold belt in the central Andes of northwestern Peru. - Mineralium Deposita, 32, pp. 149-163.

Dill, H.G., A. Fricke, K.-H. Henning, C.H. Theune 1995: Aluminium phosphate mineralization from the hypogene La Vanguardia kaolin deposit (Chile). - Clay Minerals, 30, pp. 249-256.

Hedenquist, J.W., A. Arribas, E. Gonzales-Urien 2000: Exploration for epithermal gold deposits. Reviews in Economic Geology, 13, pp. 245-277. 
Kazmin, V.G., L.E. Ricou, I.M. Sbortshikov 1986: Structure and evolution of the passive margin of the Eastern Tethys. - Tectonophysics, 123, pp. 153-179.

Köster, H. 1974: Ein Beitrag zur Geochemie und Entstehung der oberpfälzischen Kaolin-FeldsparLagerstätten. - Geol. Rundsch, 63, pp. 655-689.

Maksimovic, Z, G. Pantó 1983: Mineralogy of yttrium and lanthanide elements in karstic bauxite deposits. - Trav. ICSOBA, 18, pp. 191-200.

Meyer, C., J.J. Hemly, 1967: Wall-rock alteration. - In Barnes, H.L. (Ed.): Geochemistry of hydrothermal ore deposits. Holt, Rinehart and Winston, New York, pp. 166-235.

Pourhosseini, F. 1981: Petrogenesis of Iranian plutons a study of the Natanz and Bazman intrusive complexes. - Geological Survey of Iran, 53, 315 p.

Rye, R.O., P.M.Bethke 1992: The stable isotope geochemistry of acid sulfate alteration. - Economic Geology, 87, pp. 225-262.

Stoffregen, R., G. Cyan 1990: An experimental study of Na-K exchange between alunite and aqueous sulfate solutions. - American Mineralogist, 75, pp. 209-220.

Stoffregen, R. 1987: Genesis of acid-sulfate alteration and Au-Cu-Ag mineralization at Summitville Colorado. - Economic Geology, 82, pp. 1575-1591.

Watanabe, Y., J.W. Hedenquist 2001: Mineralogic and stable isotope zonation at the surface over the El Salvador copper deposit, Ch: 6. - Economic Geology, 96, pp. 1775-1797.

Zahedi, M. 1976: Explanatory text of the Esfahan Quadrangle map, 1:250000. - Geology Survey of Iran, F8, pp. 49. 